Cynthia M. Vakareliyska (Eugene)

\title{
Dots and Acute Accent Shapes IN THE DOBREJŠo GOSPEL
}

\section{Introduction}

$\mathrm{D}_{\mathrm{t}}$ ots, accents, and other diacritical marks positioned over letters are common features of medieval Church Slavonic manuscripts. For the purposes of this paper, these can be very generally categorized as either primarily paleographic or primarily orthographic in nature, although the boundary between the two categories is fuzzy. Paleographic diacritics generally imitate meaningful orthographic conventions in Greek manuscripts, but have only a decorative function in Slavic manuscripts, since they were not a standard part of the Glagolitic or Old Cyrillic orthographic system. These can include a regularly-occurring dot over the letter w; breathing marks over vowel letters; and apparent accent marks whose placement does not reflect the actual stressed syllable of the Church Slavonic words they appear over. In contrast, orthographic-level diacritics, which are the focus of this paper, have a disambiguating punctuational function, and serve to assist readers in parsing the text. Examples of these are acute accents placed over the stressed syllable of the words in which they appear; a regularly-occurring double dot over $\ddot{i}$ and ligated vowel letters $\boldsymbol{ю}, \ddot{\bullet} є, \ddot{ю}$, disambiguating them from $\mathbf{~}$ and other similarly-shaped letters; and a single dot or breathing mark over any vowel letter that immediately follows another vowel letter, either word-internally or word-initially.

This paper examines four unusual patterns in orthographic-level diacritical markings in the Dobrejšo Gospel, a western Bulgarian liturgical tetraevangelion generally dated to the $13^{\text {th }}$ century ${ }^{1}$. The sporadic nature of the diacritics distinguishes them from the types described above. So far I have not come across any of the four Dobrejšo

\footnotetext{
${ }^{1}$ No. 17 (307), Cyril and Methodius National Library, Sofia; typeset edition: Б. ЦонЕв, Добрейшово четвероеванелие. Среднобългарски паметник от XIII век (Софийска Нар. Библиотека No. 307 и Белградска Нар. Библиотека No. 214), БСт 1, 1906. A digital facsimile of the manuscript is available at http://www.europeana.eu/portal/en/record/2063614/BU_280_01.html. The analysis in this paper is based on my first-hand examination of the manuscript and handwritten corrections of Conev's flawed 1906 transcription edition, in connection with a second, corrected diplomatic edition and analysis of the manuscript that I am currently compiling.
} 
patterns in other medieval Slavic manuscripts, with the exception of one somewhat similar diacritic type in a few early East Slavic manuscripts (see subsection 3.1 below, n. 5). Following the overview in section 2 below, each diacritic pattern is discussed separately in sections 3 through 6 , and conclusions are presented in section 7 .

\section{Orthographic diacritics in the Dobrejšo Gospel}

The diacritics that are the focus of this study are written by the main scribe of the Dobrejšo Gospel, the priest Dobrejšo, whose name appears twice in the manuscript and whose self-portrait is included in the frontispiece to the Book of John ${ }^{2}$. Dobrejšo regularly employs double dots in $\ddot{i}$ (including in $\mathbf{\Delta} \mathbf{i}$ ) and $\ddot{\mathfrak{w}}$, and over the ligatures in "øa, $\bullet$, and" $\bullet$; and a single dot over vowel letters immediately preceded

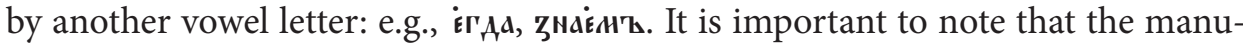
script does not mark either accentuation or, with only rare exceptions, dropped etymological weak jers.

A frequent diacritic in the Dobrejšo Gospel with an extralinguistic function is what looks like a single acute accent or a series of three acutes over or near a letter that immediately follows the large red initial letter marking the beginning of a lection: e.g., $\mathbf{G}^{\prime} \mathbf{A}^{\prime \prime}$ ава (with red $\mathbf{G}$ ). As the introduction to Conev's transcription edition of the manuscript explains, this is simply a placemarker left by the scribe for himself to show where to insert a red letter after he had completed writing a page of text in black ink ${ }^{3}$. Finally, as in very common in medieval Slavic manuscripts, there are many ambiguous superfluous dots in the Dobrejšo Gospel that look like accent marks, but that were clearly produced inadvertently as the scribe rested his pen as he consulted his copying source.

The four sporadic diacritic patterns in the manuscript that are the subject of this paper are less straightforward in function than the ones described above. Most frequent among these is a dot or a shape similar to an acute accent placed over or near the letter $\rho$ : i.e., in some places $\dot{\rho}$, in others $\rho^{\prime}$. Since distribution of the dot vs. accent shapes is random, the scribe appears to have intended both to represent a single symbol. Although Conev remarks on this diacritic in his introduction ${ }^{4}$, he does not offer an explanation for it, and apparently he did not observe any

\footnotetext{
${ }^{2}$ Although Conev expresses reservations in the introduction to his edition of the manuscript as to whether the primary scribe is priest Dobrejšo, this can be extrapolated from Dobrejšo's appearance in the frontispiece to the Book of John (fol. $72 \mathrm{v}$ ), together with the illustrator's note on the frontispiece to the Book of Luke seeking divine assistance to do a better job on the upcoming portrait of St. John (fol. 18v). Although Conev identified numerous contributing copyists, including a guest scribe who marked dropped weak jers with a double acute accent on fols. $12 \mathrm{v}$ and $13 \mathrm{r}$, the writing on both frontispieces appears to be in the hand of the primary scribe. Cf. Б. Цонев, Добрейшово четвероеванелие..., p. 16.

${ }^{3}$ Ibidem, p. 19.

${ }^{4}$ Б. Цонев, op. cit.
} 
pattern behind its occurrence. In fact, the dotted/"accented" $\rho$ most often occurs in the manuscript in canonical Old Church Slavonic (OCS) spellings of historical ${ }^{\star} \operatorname{Tr} r T,{ }^{\star} \operatorname{Tr} r T,{ }^{\star} \operatorname{Tr} r T$, and ${ }^{\star} \operatorname{Tr} b T$ formations (hereafter referred to generally as ${ }^{\star} \operatorname{Tr} r T$ and $\left.{ }^{*} \operatorname{Tr} r T\right)$ such as nipıcrts (fol. 5v5).

Less commonly, the dot or acute accent shape appears in the Dobrejšo Gospel over a letter $\rho$ adjacent to another consonant letter in words that did not historically have a jer either immediately preceding or immediately following $/ \mathrm{r} /$ in a conso-

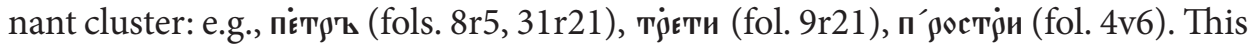
phenomenon is analyzed in section 2 below.

The second sporadic pattern, discussed in section 3.5 and 4 , is a series of two or three apparent acute accent forms over $\rho$, and from one to three acute accents or a single dot over $\boldsymbol{\lambda}$, where that letter immediately follows another consonant letter in a word that did not historically have a jer either immediately before or

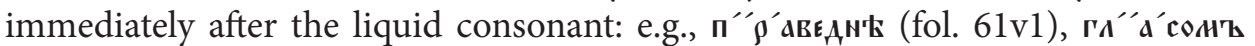
(fol. 114r6), въъгго асить (fol. 67r15), въъгіхасить (fol. 67r18). These diacritics are distinguishable from the acute shapes following a red letter that are discussed above, since they do not come at the beginning of a lection.

From one to three acute accent shapes, or, alternatively, a single dot, also occur sporadically over $\mathbf{N}$, predominantly in forms of OCS $d b n b$ : e.g., fol. $39 \mathrm{r} 2 \mathrm{~A}^{\prime} \mathbf{E}{ }^{\prime \prime} \mathbf{H L}$,

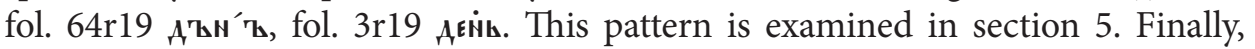
in approximately one-third of the occurrences of the OCS lexeme sqbota, there is a dot, a single acute shape, or three consecutive acute accent shapes over or near the

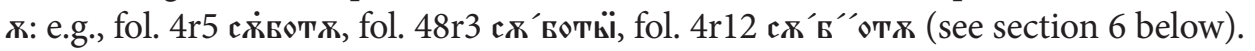

\section{Dotted/accented $\rho$}

3.1. ${ }^{*} \operatorname{Tr} r T$ and ${ }^{\star} \operatorname{Tr} \boldsymbol{r} T$ formations. As noted above, scribe Dobrejšo has occasionally placed a dot or acute accent shape over the $\rho$ in his canonical OCS spelling of words that contained a neutral jer ${ }^{5}$. Examples include the following historical ${ }^{\star} T$ Tr $T$ T formations, i.e., words with a historical neutral front or back jer immediately preceding a consonant cluster ending in /r/: fol. 4r2 в'ъстрьгати, fol. $4 \mathrm{r} 16$

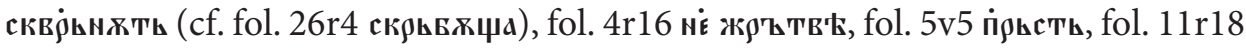

\footnotetext{
${ }^{5}$ Following H.G. Lunt, Old Church Slavonic Grammar, ${ }^{7}$ Berlin-New York 2001, p. 38-39, I use the term "neutral jer" to mean a written jer letter (usually $\mathbf{~} \mathbf{s}$ in OCS manuscripts) between the letter $\rho$ or $\boldsymbol{\Lambda}$ and an immediately following consonant letter in the same word. As Lunt observed (ibidem, p. 38), evidence from later Slavic dialects and languages suggests that in this configuration, the neutral jer letter represents a jer vowel that originally preceded the liquid consonant $/ \mathrm{r} /$ or $/ 1 /$ in Common Slavic. (Cf., in Early East Slavic manuscripts, the characteristic positioning of the jer letter to the left of the

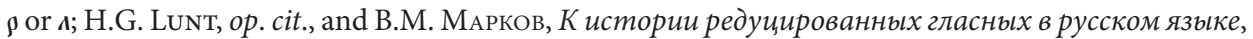
${ }^{2}$ Казань 2007, among others.) There is no attestation in OCS manuscripts of the lowering of such jer vowels to full vowels in strong position. I have extended the scope of this term in this paper to refer to phonological jers as well as orthographic jer letters.
} 


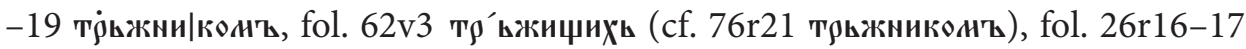

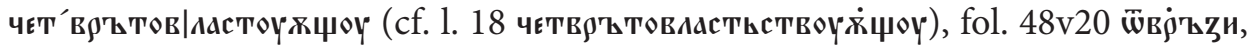

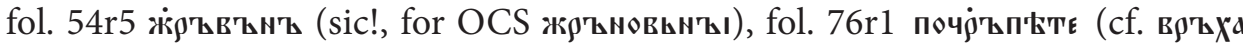
earlier on same line, fol. 78v3 почртппал). The dot or acute accent also occurs in words that contain historical Common Slavic ${ }^{\star} \operatorname{Tr} r T$ formations, in which the jer followed the /r/: for example, fol. 47v22 ш̈к' көлъви (with a barely visible dot). That the convention covers both historical ${ }^{\star}$ Tъr $T$ and ${ }^{\star} \operatorname{Tr} \approx T$ roots is unsurprising, of course, since both formations are believed to have merged into the syllabic liquid formation TRT in Early South Slavic before being reanalyzed in OCS solely as the formation ${ }^{\star} \operatorname{Tr} \boldsymbol{T} T$ (but cf. Bulgarian and Macedonian dialects, in section 3.4 below) ${ }^{6}$.

This sporadic diacritic is similar to the fairly regular use of a dot over a consonant letter that immediately precedes either $\rho$ or $\boldsymbol{A}$ in some East Slavic manuscripts, including the Archangel Gospel and the $11^{\text {th }}$-century Putjata Menaion ${ }^{7}$, to mark a vocalic element before the liquid consonant in OCS trat and trat forms ${ }^{8}$. In contrast to the East Slavic manuscripts, however, no equivalent diacritic ever occurs over the letter $\boldsymbol{\Lambda}$ in Dobrejšos canonical OCS spellings of historical ${ }^{\star} T z l T /{ }^{\star} T b l T$ formations (both hereafter ${ }^{\star} T \boldsymbol{b} l T$ ), or ${ }^{\star} T l_{b} T{ }^{\star}{ }^{\star} T l b T$ formation (both hereafter ${ }^{\star} T l b T$ ), such as This lack of symmetry may explain why Conev failed to recognize the meaning of the diacritics over $\rho$, despite the fact that his introduction discusses the representation of roots containing neutral jers ${ }^{9}$. Indeed, in the introduction Conev has more to say about ${ }^{\star} T \mathfrak{b} l T$ roots than ${ }^{\star} T \mathfrak{r} r T$ roots: he lists 31 instances of historical ${ }^{\star} T \mathfrak{b} l T$ forms in the manuscript in which the jer precedes the $\boldsymbol{\Lambda}$ rather than following it as

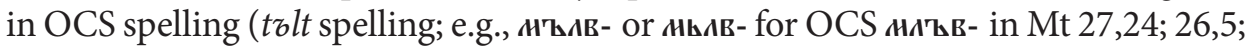
$26,63$; Mc 5,39; 9,23; Lc 10,40 $)^{10}$. A parallel spelling pattern of tzrt for historical ${ }^{\star} \operatorname{Tr} r T$ or ${ }^{\star} \operatorname{Tr} \varpi T$ formations does not occur anywhere in the manuscript ${ }^{11}$.

\footnotetext{
${ }^{6}$ On the development of new syllabic liquids in Middle Bulgarian, see A.-M. Тотоманова, За природата и съдбата на гласната ^ в българския език, [in:] ЕADEм, Из българската историческа фонетика, София 2001, p. 45-67 (57).

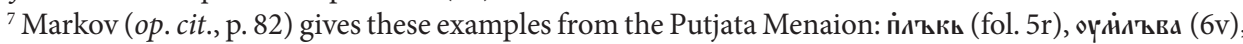

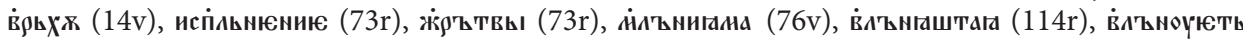

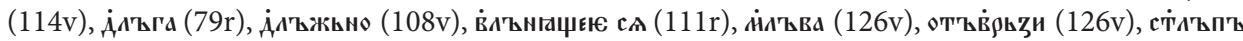
(134); see also discussion on p. 93.

${ }^{8}$ B.M. МАРКОВ, op. cit., p. 82.

${ }^{9}$ Б. Цонев, op. cit., p. 55-56.

${ }^{10}$ Conev provides a list of 34 instances of what he calls $z p$ and $z \pi$ spellings (referred to in this paper as tort and $t z l t$, where $t$ represents any consonant letter and $\tau$ represents either jer letter). Cf. Б. ЦонЕВ, op. cit., p. 56. All but three of these are with $\boldsymbol{\Lambda}$, and one is incorrect: Conev has mistakenly included

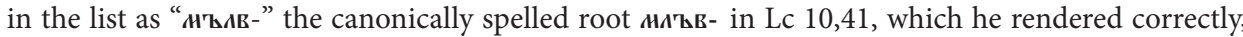
however, in the transcription portion of the edition. Moreover, three of the instances that Conev lists as tzlt spellings in the manuscript actually are spelled $t z l z t$; see discussion in section 3.3 below. ${ }^{11}$ The three instances that Conev includes in his list as tort spellings in the Dobrejšo Gospel actually have the form torot, not tort; see discussion in section 3.3 below.
} 
To summarize, the Dobrejšo Gospel's sporadic non-canonical spellings of historical neutral jer formations are in complementary distribution. Historical ${ }^{\star} T \mathfrak{b} l T$ and ${ }^{\star} T l_{r} T$ formations occasionally are written as $t z l t^{12}$, but historical ${ }^{{ }^{*} T r} r T$ and ${ }^{\star} \operatorname{Tr} \tilde{} T$ are not written as tzrt (with the exception of a correction of a tzrøt spelling, discussed in 3.2 below). Instead, while generally the historical ${ }^{\star} \operatorname{Tr} T{ }^{\star}{ }^{\star} \operatorname{Tr} r T$ formations appear in the manuscript in the canonical OCS spelling trat, sporadically a dot or a mark that looks like an acute accent (i.e., a longish diagonal line ascending upward to the right) is placed over or near the $\rho$ (hereafter referred to as 'dotted/“accented" $\rho$ '). This diacritic does not appear correspondingly over $\boldsymbol{A}$ in historical ${ }^{\star} T z l T$ or ${ }^{\star} T l z T$ forms.

3.2. Trrot and trlat spellings. Conev's introduction obscures the issue of the distribution between 'dotted/"accented" $\rho$ ' and tolt spellings in the manuscript, because seven of the forms in his list of what he claims are tort or tolt spellings

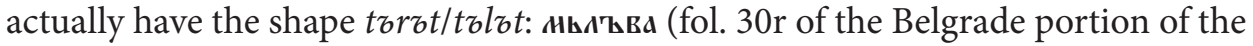
manuscript, which was lost during World War II), в'ъльк' (fol. 38v, Belgrade

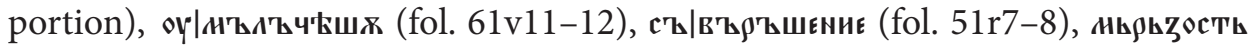

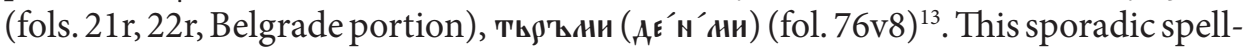

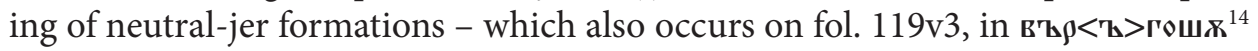
- is the only one that is used in the manuscript to represent both OCS trot and tlot forms.

The torbt/tzlzt orthographic forms in the Dobrejšo Gospel are graphically identical to the secondary pleophony spellings in East Slavic manuscripts. Both Conev and Koneski treat these essentially as $t$ tr $r$ t/tzlt spellings, however, listing them together with the tzlt examples ${ }^{15}$ - although Conev argues that in tzizt forms the copyist was deliberately preserving the OCS spelling while at the same time also deliberately inserting a jer before the $\boldsymbol{\Lambda}$ to represent his own dialect pronunciation. If both jers in the tribt spelling were indeed deliberate, however, then it is puzzling why this spelling is so rare in the manuscript. A more likely explanation is that scribe Dobrejšo was striving throughout to reproduce canonical OCS spelling and to suppress orthographic expression of the tzlt feature in his vernacular dialect, but that the dialect feature occasionally crept in nevertheless, both in the superfluous jer in the three tzizt forms, and in the 30 tzlt forms, which occur

\footnotetext{
${ }^{12}$ Since the Dobrejšo Gospel's sporadic talt spelling is not a feature of its close relatives, the Curzon and Banica liturgical gospels, it must be a fairly late development in the manuscript's prehistory. Cf. Add. MS 39,628, British Library, London, c.1354; typeset edition by C.M. VAKareliYsKa, The Curzon Gospel, vol. I, An Annotated Edition, vol. II, A Linguistic and Textual Introduction, Oxford 2008; НБКМ No. 17, Cyril and Methodius National Library, Sofia; typeset edition by Е. ДограмАджиЕвА, Б. РАйков, Банишко евангелие. Среднобългарски паметник от ХІІІ век, София 1981.

${ }^{13}$ Б. Цонев, op. cit., p. 56.

${ }^{14}$ The symbol $<>$ represents an erased segment.

${ }^{15}$ Б. Цонев, ор. cit., p. 56; Б. Конески, История на македонскиот јазик, Скопје 1965, р. 33.
} 


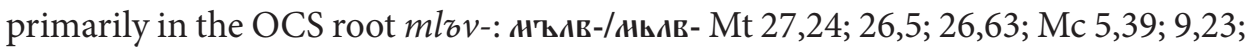

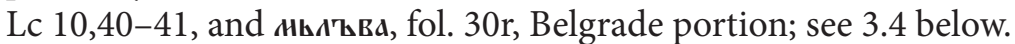

The four trrbt occurrences in the manuscript are difficult to explain as failures to suppress a tzrt dialect feature, because the Dobrejšo Gospel has no occurrences of unambiguous tzrt spellings to suggest that the extra jer in trrbt results from a combination of OCS trot and vernacular tzrt spelling variants, whether deliberate or not ${ }^{16}$. This differs from the situation in East Slavic manuscripts, which can contain both tzrot/tzlzt and tzrt/tzlt spellings of the same word.

\subsection{Tolt, tolot, trrot, and dotted/“accented" trot spellings within the context} of modern Bulgarian and Macedonian dialects. While it must be kept in mind that not all features of modern Bulgarian dialects date back to Middle Bulgarian vernaculars, a brief look at the Dobrejšo Gospel's various OCS trot and tlzt representations from the perspective of Bulgarian and Macedonian dialects is nevertheless somewhat instructive with respect to any phonological significance of the asymmetry in the manuscript's sporadic torzt, tolot, and dotted/“accented" trot spellings.

Considering first the sporadic dotted/“accented” $\rho$ in the Dobrejšo Gospel's trat spellings, which seems to be indicating a non-OCS phonological treatment of the neutral jer, might the diacritic be intended to mark a syllabic /r/? The manuscript

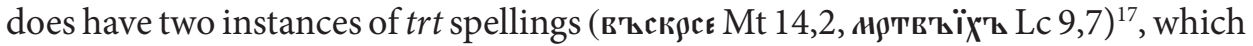
Blaže Koneski identifies in the twelfth-century Ohrid Apostolus, and other Macedonian manuscripts of the same general time period, as a reflection of a syllabic liquid $^{18}$. Koneski's examples from the Ohrid Apostolus include плна and нотвых $\mathbf{X}^{\mathbf{2}}$

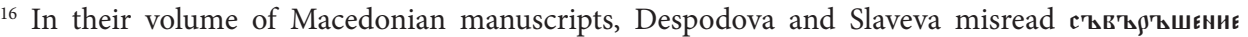
in Conev's introduction as с'ъв'ършєние, and thus presented it as an example of sporadic tort spellings in the Dobrejšo Gospel, when in fact the manuscript has none of these, with the exception of the cor-

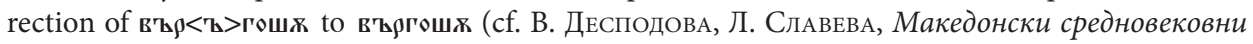

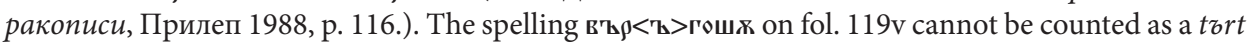
spelling, however, because the erasure probably was made by a later editor. This is suggested by the fact that the erasure in the manuscript leaves a gap in the word and is not written over. In any event, in contrast both to Koneski and to Despodova and Slaveva, I find the Dobrejšo Gospel generally to reflect western Bulgarian rather than Macedonian phonological features (cf. C.M. VAKARELIYSKA, Western Bulgarian or Macedonian? The Dobrejšo Gospel (XIII c.), Slo 50, 2010, p. 13-26, http://www. moderna.uu.se/slovo/Issue_Pages/2010issue50.html [14 XII 2014]). Also relying on p. 56 of Conev's introduction, Horace Lunt specifically mentioned the Dobrejšo Gospel's tzrøt/tzlzt spellings in his article on syllabic liquids, but stated generally that the Dobrejšo Gospel has more of what he called "jer + liquid" spellings than the earlier Bologna Psalter, since Conev's discussion does not indicate that that the "jer + liquid" spelling occurs only as tolt and not tort (cf. H.G. LunT, Old Church Slavonic Syllabic Liquids?, WS 7, 1962, p. 350-358 (p. 358, n. 21)).

${ }^{17}$ The numbers provided in this paper are based on a single preliminary search through the manuscript; hence there may be some other instances that I have missed this time round.

${ }^{18}$ Б. Конески, ор. cit., p. 33.
} 
the latter of which is, coincidentally, precisely the same form that appears in the Dobrejšo Gospel ${ }^{19}$. In contrast to the trt spellings in the Ohrid Apostolus however, the Dobrejšo Gospel's two occurrences of trt without a diacritic are in words that routinely are written with a titlo, which indicates that they are abbreviated: i.e.,

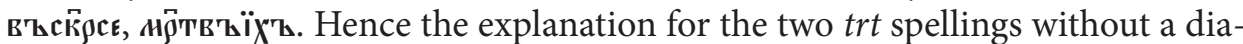
critic in the manuscript must be that they were intended as the usual abbreviated forms, but that scribe Dobrejšo inadvertently omitted the titlo over them ${ }^{20}$.

Even if there were evidence to support the claim that the Dobrejso Gospel's dotted/"accented" $\rho$ reflects a syllabic/r/, however, it would not be an indicator that the manuscript is Macedonian, as Koneski assumed, for two reasons. First, all of the Dobrejšo Gospel's other Macedonian-type features are found also in its close relatives the Curzon and Banica Gospels ${ }^{21}$, indicating that they predate the three manuscripts and stem from their shared common source ${ }^{22}$. Second, if modern dialects are any indication, the 2001 Bulgarian Academy of Sciences dialect atlas shows syllabic/r/ for OCS $r \varpi / r b$ in dialects as far east as Teteven ${ }^{23,24}$.

${ }^{19}$ Potentially relevant for the Dobrejšo Gospel's orthographic asymmetry between dotted/“accented" trøt and $t$ tolt is Koneski's comment here that while some Macedonian dialects have both syllabic/r/ and /l/, others have only syllabic/r/. Cf. Б. Конески, op. cit.

${ }^{20}$ Some, but not all, of the examples cited by Koneski from other manuscripts are forms that could also simply be missing a titlo: e.g., нотвы in the thirteenth-century Macedonian Gospel, and in the Bologna Psalter, from the same century. That too much should not be read into the occurrence of such written forms without a titlo is suggested by дв $13^{\text {th }}$-century East Slavic Sofia Menaion, which presumably does not reflect a trt dialect, and which

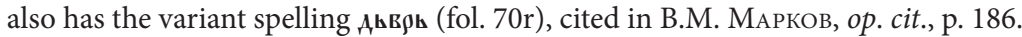

${ }^{21}$ Curzon Gospel: Add. MS 39,628, British Library; typeset edition by C.M. VAKARELIYsKa, op. cit.; Dobrejšo Gospel: НБКМ No. 17 (307), Cyril and Methodius National Library, Sofia; typeset edition by Б. Цонев, op. cit.

${ }^{22}$ For further discussion, cf. C.M. VAKareliyska, Western Bulgarian or Macedonian...

${ }_{23}^{23}$ Български диалектичен атлас. Обобщаващ том, vol. I-III, Фонетика, Акцентология, Лексика, еd. И. Кочев et al., София 2001, F 142.

${ }^{24}$ Scatton's 1994 study of modern Bulgarian dialect patterns in the distribution of the segments / $\breve{u r} /$ and / rŭ / raises a pertinent issue about the reliability of the 1981 Bulgarian Academy of Sciences dialect atlas that must be considered with regard to the 2001 atlas also (E. SCATton, Syllabic [r] and Schwa-[r] Sequences in Bulgarian Dialects: I. The Northwest, [in:] Alexander Lipson: In Memoriam, ed. C.E. Gribble, R.A. Rothstein, E.C. Haber, H.M. Olmsted, R. Szulkin, C.E. Townsend, Columbus 1994, p. 232-249 (241-42)). Noting Lehiste and Popov's findings that there is only a barely discernible acoustic difference between Bulgarian and Bosnian-Croatian-Serbian cognate pairs with /ŭr/ vs. syllabic /r/ (I. Leniste, K. Popov, Akustische Analyse bulgarischer Silbenkerne, Phon 21, 1970, p. 40-48), and Trubetzkoy's proposition that a language with /ə/ in its phonemic inventory will treat a syllabic liquid as a combination of /ə/ and liquid (N.S. Trubetzkoy, Grundzüge der Phonologie, TCLP 8, 1938, p. 54), Scatton concluded that because Bulgarian has the phoneme /ŭ/ and Serbian does not, therefore Bulgarian linguists, being influenced by the phonemic system of Bulgarian, will likely perceive a sequence of two segments in the same dialect form of a historical ${ }^{\star} \operatorname{Tr} r T$ or ${ }^{\star} \operatorname{Tr} z T$ formation where Serbian linguists, influenced by the phonemic system of Serbian, will likely perceive a single syllabic liquid. Hence, he argued, since the students who were collecting the dialect data for 


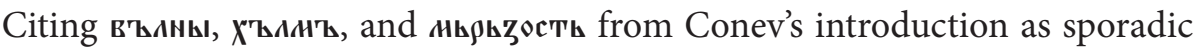
tolt and tort spellings in the Dobrejšo Gospel, Koneski stated that the jer preceding the liquid consonant letter reflected the dark vocalic overtone [темниот вокален призвук] before the syllabic $\mathrm{r}$ and $1^{25}$, going on to note that most modern Macedonian dialects are characterized by the development of a similar vocalic element (вокален пристаn) before a liquid into a full vowe ${ }^{26}$.

In assuming that both the trort/tolot and the tolt spellings in the Dobrejšo Gospel represent a single reflex of ${ }^{\star} T$ tzr $T{ }^{\star}{ }^{\star} T$ z $l T$ forms in the scribe's dialect, both Conev and Koneski were apparently unperturbed by the fact that the same reflex is expressed by two different spelling conventions. It may be for this reason that Conev, and those scholars who relied on his description, did not differentiate between the exceedingly rare torbrt/tolot spellings in the manuscript, on one hand, and tolt and (actually non-existent) tort spellings, on the other. (Since Conev had not observed the sporadic dotted/“accented" $\rho$ and its potential phonological significance, of course Koneski was unaware that there was another possible marker of a vocalic element preceding what at least used to have been a syllabic liquid.)

Some support for the proposition that the torot spelling in the Dobrejšo Gospel reflected a vocalic element both before and after /r/ can be found in Miletičs transcription of the sequence he transcribes as $\underset{o}{\arg }$ (that is, /ŭrŭ/) for CSB / ŭr/ in early twentieth-century Preslav-area dialects (in the sole example marazlivičkz) ${ }^{27}$, but a relationship between this feature of certain eastern Bulgarian dialects and the western Bulgarian Dobrejšo Gospel would be tenuous. Moreover, Miletič provided no equivalent sequence of /ŭlŭ/ for / ŭl/ that might offer a parallel phonological explanation the manuscript's tolot spellings.

The apparent absence of Bulgarian dialect /ŭlŭ/ forms corresponding to Miletičss single /ŭrŭ/ example reflects the general asymmetry in many Bulgarian

the 1981 Bulgarian dialect atlas did not use acoustic measurements, the phonetic values that they recorded for the reflexes of ${ }^{\star} T r R T$ and ${ }^{\star} \operatorname{Tr} r T$ formations could be simply the values that they were perceiving under the influence of the general phonemic system of Contemporary Standard Bulgarian (CSB). Consequently, he questioned the accuracy of any transcriptions of a syllabic/ $\mathrm{r} /$ in Bulgarian dialects that have the vowel /ŭ/, citing Trubetzkoy's statement that recorded differences could simply reflect variations in tempo or emphasis caused by extralinguistic factors. Horace Lunt made a similar observation about South Slavic syllabic liquids earlier, grounded in the same work by Trubetzkoy: The descriptions of dialects vary considerably according to the perception of the observer, and one must always reckon with the automatic subjective reaction based on the situation on the observer's native speech. Thus Serbs and Bulgars recording the same Macedonian words will write now trt, now ţrt or trъt (...). H.G. LunT, Old Church Slavonic Syllabic Liquids?, WS 61.2, 1962, p. 353, n. 14.

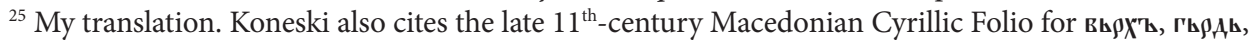

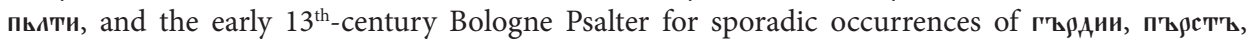
м'ълинг. С.. Б. КОНЕСКИ, ор. cit.

${ }^{26}$ Koneski also notes that in some southeastern Macedonian dialects, the vowel develops following the liquid (grŭb, vrŭx, trŭgna, vlŭk, žlŭt). Ibidem.

${ }^{27}$ LJ. Miletič, Südslavische Dialektstudien, vol. II, Das Ostbulgarische, Wien 1903, p. 75. 
and Macedonian dialects between the reflexes of ${ }^{\star} T z R T$ and ${ }^{\star} T z L T$ - an asymmetry that also likely is behind the distribution of dotted/"accented" trot vs. tzlt spellings in the Dobrejšo Gospel. For example, the 2001 Academy dialect atlas records syllabic/r/ in Teteven, Vraca, Blagoevgrad, Trŭn, Skopje, and Niš, as opposed to syllabic /l/ in Teteven, Vraca, Vidin, Sofia and Trŭn ${ }^{28}$, thus demonstrating that in some dialects, ${ }^{\star} T z R T$ and ${ }^{\star} T z L T$ reflexes have not evolved in parallel. Moreover, not only does the 2001 atlas record more variation and inconsistency in ${ }^{\star} T z L T$ reflexes than in ${ }^{\star} T z R T$ reflexes, but it also includes maps devoted to the geographic distribution of the reflexes of specific ${ }^{\star} T z L T$ roots (OCS $v l_{b} k \mathfrak{b}, d l_{b} g z$, $\check{z} l b t$ ) that tend be exceptions to the usual ${ }^{\star} T z L T$ reflexes in some dialects ${ }^{29}$. No similar set of maps is provided for the reflexes of any ${ }^{\star} T z R T$ roots. Similarly, Bojadžiev observed in his study of Thracian dialects that ${ }^{\star} T z L T$ and ${ }^{\star} T z R T$ reflexes are often flexible and even word-specific, as in želt for OCS žlotr but dlek for $d l i g z^{30}$. The existence of specific roots in tzlt in some dialects that usually exhibit tlot suggests that the Dobrejšo Gospel's higher occurrence of tritt spellings with OCS root $m l s v$ - is not coincidental, but that it instead reflects a similar word-specific pattern in ${ }^{\star} T z L T$ reflexes in the scribe's vernacular. If so, the scribe may have found it more difficult to suppress the tzlt spellings of words that took exceptional tzlt or telt shapes in his dialect.

Bojadžiev's examples of discrepancies within individual dialects include the Dedagackso and Lozengradsko dialects, which have both /ŭr/ and /rŭ/, and /ŭl/ and /lŭ/, in monosyllabic forms and in polysyllablic forms with a single consonant following the liquid ${ }^{31}$; the Odrinsko dialect, which has /ŭr/-/rŭ/ variation, but only /ŭl/, in monosyllabic forms ${ }^{32}$; the Malgarsko and Kešansko dialects, which exhibit sørp, grrk, volk, prl, žzlt/ želt, and dlek but pros, tløs ${ }^{33}$; and the dialects of Silivrija, Čorlu and Carigradsko/Čataldžansko, which have grok, pløx, vrox , tløs, the doublets brøs/børs (Čanakča), vølk/vløk (Dajakadŭn and Tarfa), and ž̋lt/žløt (Tarfa), and polysyllabic grcki with two consonants following the liquid, but no equivalent in polysyllabic forms in $/ 1 / .^{34}$

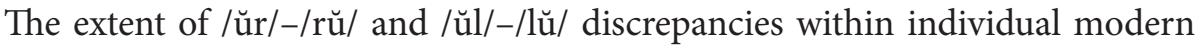
dialects - not to mention within CSB itself - suggests that there is no reason to assume that the sporadic non-OCS spellings of either ${ }^{\star} T$ tr $r T$ or ${ }^{\star} T z l T$ reflexes reflect consistent phonological features in the Dobrejšo scribe's vernacular dialect either.

\footnotetext{
${ }^{28}$ Български диалектичен атлас..., F 142, 146. See also discussion of syllabic/r/ and /l/ in J. DumA, Wokalizacja jerów słabych $w$ rdzennej sylabie nagłosowej w południowo-wschodniej słowiańszczyźnie, Wrocław 1979, p. 19 (map 12), 20 (map 14), 21 (map 16), 45.

${ }^{29}$ Български диалектичен атлас..., F 150, 151, 152.

${ }^{30}$ Т. Бояджиев, Български говори в западна /беломорска/ и източна /одринска/ Тракия, София 1991.

${ }^{31}$ Ibidem, p. 134, 149.

${ }^{32}$ Ibidem, p. 142-43.

${ }^{33}$ Ibidem, p. 185.

${ }^{34}$ Ibidem, p. 192.
} 
3.4. Titla over non-abbreviated OCS trzt spellings. In opposition to the Dobrejšo

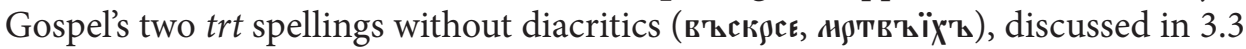
above, considerably more frequently a titlo appears over an unabbreviated canonical OCS trot spelling in which the jer has not been omitted. These occasional titla appear predominantly over the same two roots that occur once apiece as trt spell-

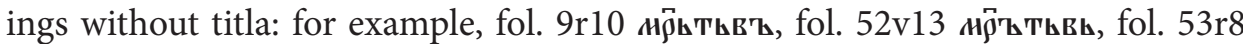

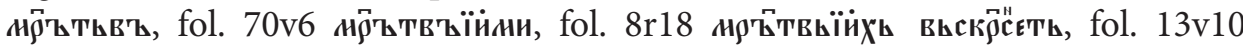

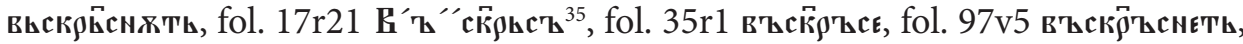

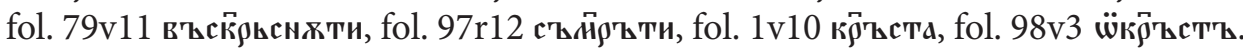
These titla likely have no phonological significance and are simply automatic, since they are limited to OCS trøt forms that commonly are abbreviated in Church Slavonic manuscripts. That is, the scribe has inserted a titlo out of habit after he has already written the form in full, including the jer. In this respect the titla over unabbreviated trot word forms in which the neutral jer is still present differ from the sporadic dot or acute accent shape over the $\rho$ in trot forms, which appears over both commonly abbreviated forms and forms that are not generally abbreviated.

3.5. Dotted/“accented" $\rho$ in non-trøt consonant clusters. Although a dot or accent shape over or near an $\rho$ occurs most frequently in OCS trot spellings, it can be found in the manuscript also over forms containing a consonant cluster ending in $/ \mathrm{r} /$ that never included a historical neutral jer. I have observed the following forms with non-trøt dotted/“accented" $\rho:$

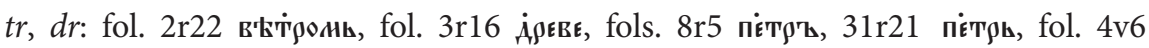
п'

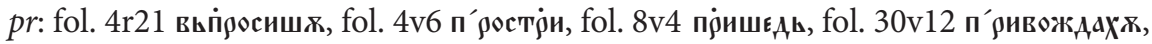

fol. 25v10 паскы (originally праскы, with erased $\rho$ )

$v r$ : fol. 1v5 врंаzи

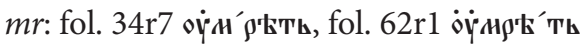

While it is possible that one or more of the above diacritics are simply resting points, their distribution indicates that at least the majority of them are deliberate. In three of the six OCS forms above with dental clusters, the historical $/ \mathrm{tr} / \mathrm{or} / \mathrm{dr} /$ later developed into /tŭr/ or /dŭr/, respectively, in CSB (vjatŭr, dŭrvo, Petŭr), suggesting that the diacritic over the $\rho$ marks an immediately preceding vocalic element, as it likely does in the dotted/"accented" trot spellings. The preceding vocalic element that is suggested by the two instances of dotted/"accented" $\rho$ in OCS aorist umrětz is less interesting, of course, since it likely developed by analogy to the non-past stem $u_{m z r}{ }^{36}$.

\footnotetext{
${ }^{35}$ Conev's typeset edition omits the titlo in this example.

${ }^{36} \mathrm{~A}$ dot is used over the first of two consecutive consonant letters in non-trat (and non-tlat) formations also in the East Slavic Putjata Menaion, and in a broader range of environments than in the
} 
The manuscript also contains four instances of double or triple acute accent shapes in historical non-trot forms. To demonstrate that the accent shapes do not correlate to sentence stress or location, I have included the textual context for

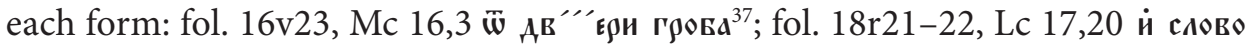

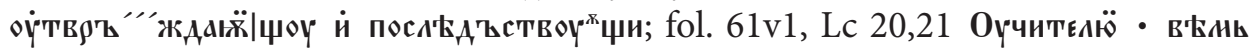

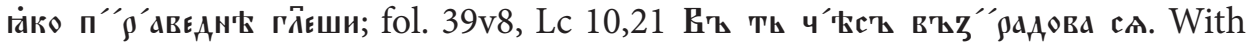
the exception of $\mathbf{B}^{\prime} \mathbf{z} \mathbf{z}^{\prime \prime}$ " simply be marking the location of the beginning of the lection text following the

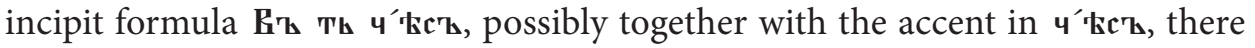
appears to be no relation between the acute accent shapes in these occurrences and the location of the lexeme either syntactically or within the lection. Instead, like the single diacritics above, the double or triple acute accent shapes in these forms appear to be indicating a vocalic element between the first consonant in the cluster and the $/ \mathrm{r} /$. There is also a single instance of a dot over $\boldsymbol{A}$ in a non-trot

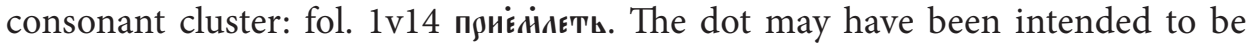
placed over the segment n $\rho$, or it could be an inadvertent resting point. On the other hand, if, as other spellings in the manuscript suggest, Dobrejšo's dialect did not retain epenthetic $/ 1 /$, the dot could be appropriately be marking word-internal $/ \mathrm{ml} /$ as an unnatural consonant cluster ${ }^{38}$.

A related orthographic pattern in the Dobrejšo Gospel that sheds some light on the meaning of the dotted/"accented" $\rho$ in OCS trot and non-trøt forms alike (as well

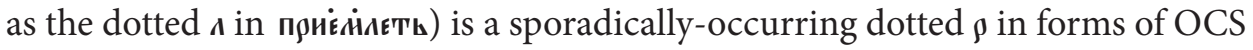

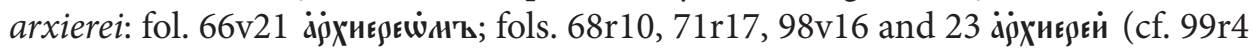

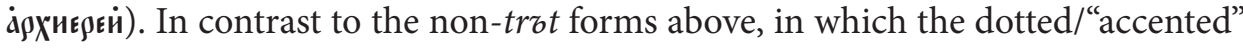
$\rho$ immediately follows another consonant letter in a cluster, in arxierei the $\rho$ is the first consonant letter in the cluster. It is telling that this particular Greek borrowing is often written in other Church Slavonic manuscripts with a jer or a paerok between the $\rho$ and the $\chi$, as if it were an etymologically Slavic word, in order to break up the consonant sequence /rx/, which was not a natural cluster in Slavic vernaculars. Like the dotted/"accented" $\rho$ in trot spellings, the occasional dot or accent shape over the first $\rho$ in arxierei appears to be indicating a vocalic element between the consonants $/ \mathrm{r} /$ and $/ \mathrm{x} /$, while at the same time preserving the canonical OCS spelling. This diacritic has essentially the same function as the dot in some

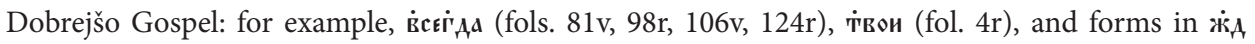
(B.M. МАРКОВ, op. cit., p. 93).

${ }^{37}$ Cf. диври in Mt 25,10, Lc 13,25, and Io 10,7 and 9 of the Curzon Gospel. See also A.-M. ТотомA-

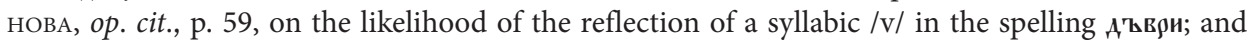
J. Duma, op. cit., on syllabic/v/ in southeastern Slavic dialects, p. 49.

${ }^{38}$ On this issue, see C.M. Vakareliyska, The Dobrejšo Gospel... Cf., however, the high frequency of word-initial $/ \mathrm{ml} /$ in forms of mladr and mlěko, which are never marked with a diacritic in the manuscript. 
Greek manuscripts that is placed over word-final consonant clusters, which were unnatural in Greek, and it may well have been adopted from Greek manuscripts ${ }^{39}$.

The occurrence of a dot over the $\mathfrak{c}$ in the Slavic form nicors on fol. 5r18, the first in a series of two letters representing obstruents, offers further evidence that a diacritic above or near $\rho$ immediately following or preceding another consonant letter marks what would be an unnatural consonant cluster in etymologically Slavic words. The word-initial cluster /ps/ did not exist historically in Common Slavic until the loss of the weak jer in forms of prsz that ended in a full vowel, and in the root pbs- 'write' (cf. later regularized pis-). Scribe Dobrejšo may have perceived a vocalic element between the two obstruents in this form in the same way that Bulgarian speakers might perceive an / $\breve{\mathrm{u}} /$ before or after the /r/ Serbian trt forms (see section 3.3 above). In borrowings with initial cluster /ps/, such as $p s a l m z$, he avoids this issue by using the Greek digraph $\psi$, but he feels obliged to write the initial cluster in OCS prsomz as $n \dot{\boldsymbol{c}}$ because the word is Slavic. It is fortunate that he did not circumvent the problem by writing out the first weak jer rather than inserting the diacritic, but instead left this indirect evidence the function of the diacritic over the letter $\rho^{40}$.

In the forms of arxierei above, the dot seems to function as a paerok, although no jer is written between the $/ \mathrm{r} /$ and $/ \mathrm{x} /$ in this word in OCS. While the /rx/ cluster in arxiere $i$ is not native to Slavic cluster, some of the consonant clusters shown above that the Dobrejšo Gospel has sporadically marks with a dotted/"accented" $\rho$ are native and fairly high-frequency, including as /tr/ and, particularly, /pr/, which occurs word-initially in several different prefixes and in the preposition prědr. Relevant here is Lunt's observation that numerous regional dialects of Standard American English, including his own, have a liquid /r/ following initial /p/ in unstressed syllables of certain words, including 'perplex', 'propose', and 'prevent', and that he vacillated between transcribing these in his own idiolect as, for example, /pərpléks/ vs. /prpléks/ ${ }^{41}$.

\footnotetext{
${ }^{39}$ I am most grateful to Mary MacRobert for pointing out to me the convention in some Greek manuscripts of inserting a diacritic over word-final consonant clusters (personal communication, May 2016; see also B.M. Metzger, Manuscripts of the Greek Bible: Introduction to Paleography, Oxford 1981, p. 3, describing the diacritic in that environment as looking like a grave accent or a smooth breathing mark), and for her comments on the significance of the distribution of $n \dot{\boldsymbol{c}}$ and $\Psi$ in the manuscript. Of course, I am solely responsible for any misunderstanding or misapplication of this information. Cf. the use of a kamora to mark stress after a sonorant in the much later Russian Pandekt of Nikon Černogorca (1570) (В.В. Колесов, Надстрочные знаки «силь» в русской орфограбической традиции, [in:] Восточнославянские языки. Источники для их изучения, еd. Л.П. ЖуКОВСКАЯ, Н.И. ТАРАБАСОВА, Москва 1973, р. 228-257 (242).

${ }^{40}$ Note a similar dot in п்саниєн'ъ in the $11^{\text {th }}$-century East Slavic codex of the Thirteen Homilies of St. Gregory of Nazianzus (fol. 297r.) and in the Greek borrowing nicadArex' in the Ostromir Gospel; see B.M. МАРКОВ, op. cit., p. 151.

${ }^{41}$ H.G. LunT, Old Church Slavonic Syllabic Liquids?..., p. 354, n. 12.
} 
These facts together suggest that Dobrejšos tzrot and tżlot spellings indicate a vocalic element that he perceived to occur before the liquid consonant in the cluster in that particular word, either in addition to, or, more likely, instead of, the vocalic element represented by the jer following the $\rho$ or $\boldsymbol{a}$ in the canonical OCS spelling. Similarly, the dotted/"accented" $\rho$ adjacent to another consonant letter in both trat and non-trot spellings, likely reflects his perception of a vocalic element between the two consonants. The reason that vocalic elements are indicated by a diacritic rather than by a jer is probably because Dobrejšo was striving to reproduce OCS and had no interest in replacing the OCS spelling with a phonemic transcription of his vernacular. ${ }^{42}$ Hence the diacritic probably was intended to convey that the reader either should, or could (but did not have to), read aloud the word with a left-adjacent vocalic element rather than a right-adjacent one as the OCS spelling indicated. The reason why a corresponding dot does not occur over the letter $\boldsymbol{A}$ in the manuscript's OCS tlat spellings likely is that while Dobrejšo's dialect was characterized, at least inconsistently, by tort forms, it had primarily tlot forms, with the exception of certain roots in tzlt that occasionally appear spelled in the manuscript as they likely were pronounced in that dialect ${ }^{43}$.

\section{Dotted/“accented” A}

The dots and acute accent shapes that occur over the letter $\boldsymbol{s}$ in the manuscript have a distinctly different function from that of the sporadic dots and acute accent shapes over $\rho$. None of these occurs in a historical ${ }^{\star} T z L T$ or ${ }^{\star} T L z T$ formation, and in all but one instance, they appear in a word formed from the root glas-:

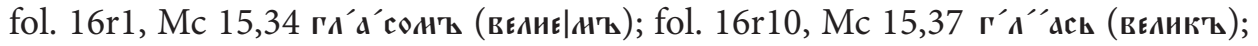

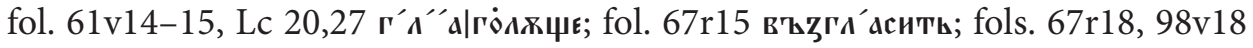

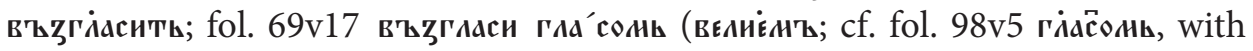

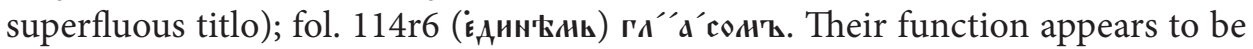
punctuational, aiding the reader to distinguish forms in glas- from the very highfrequency abbreviation rīa for the third person singular aorist form glagola ${ }^{44}$.

\footnotetext{
${ }^{42}$ For other examples of Dobrejšo's efforts to preserve OCS orthographic and morphological forms, see C.M. Vakareliyska, The Dobrejšo Gospel: An Annotated Edition and Comparative Analysis (forthcoming).

${ }^{43}$ See discussion of telt pronunciation in specific words in modern Bulgarian dialects, above in section 3.3. That the telt spellings in the Dobrejšo Gospel likely are Dobrejšo's and not a predecessor scribe's is suggested by the absence of these spellings in the related Curzon and Banica Gospels (cf. C.M. Vakareliyska, The Curzon Gospel..., chapters 2 and 4).

${ }^{44}$ The possibility must also be considered that a secondary function of the triple acute accent shapes in this environment is to indicate a perceived vocalic element between the /g/ and /1/. If so, the vocalic element would probably be similar to the inserted /ə/ between $/ \mathrm{p} /$ and $/ \mathrm{l} /$ in emphatic or facetious pronunciation of the word "please" in numerous American English dialects. The spelling "puh-leeze" for emphatic/facetious "please" is even sometimes listed in online dictionaries as a separate lexeme.
} 


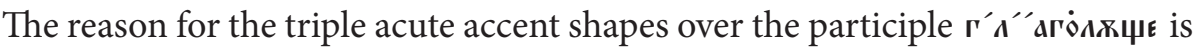
similar, but more complex. Dobrejšo usually abbreviates participial forms of glagolati, using a titlo. Here he has not, because he began the word at line-end, and

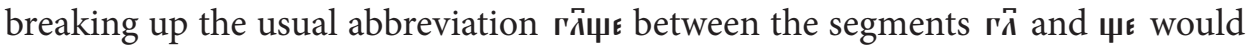
result in ending a line with a consonant letter, making the abbreviation difficult to parse. Therefore, having started the word already, Dobrejšo has decided to write it out in full instead, but has only enough room to add the a after $\mathbf{r} \boldsymbol{s}$ on the first line. This means that readers likely would misread the segment $\mathbf{r} \boldsymbol{A} \mathrm{a}$ as the abbreviation of the 3PSg aorist glagola, with the titlo missing (exactly the scenario that Dobrejšo has tried to avoid by inserting diacritics over words in glas-). Furthermore, if lineend rad is read as glagola, the repetition of the segment gol on the following line $(-\Gamma \dot{0} \Lambda x \psi \varepsilon)$ would further throw the reader off. Therefore, he has added the triple acute accent shapes over the $\boldsymbol{\Lambda}$, as he has done earlier on occasion over forms with the root glas-, in order to clarify that the line-end segment is not the abbreviated aorist $\Gamma \bar{A} \mathrm{a}$, but rather the beginning portion of a different form that continues onto

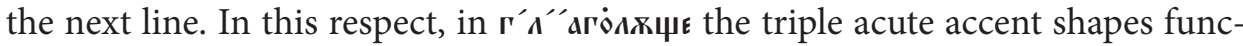
tion essentially as a hyphen ${ }^{45}$.

\section{Dotted/“accented” N}

From one to three acute accent shapes, and in one instance what looks more like

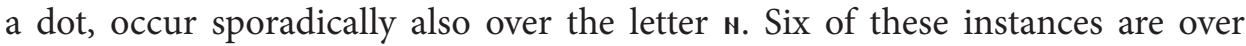
forms with root $d b n$-. These are shown here in their syntactic and textual contexts:

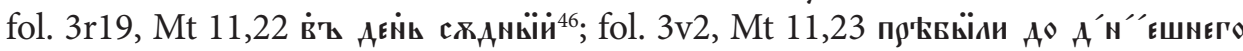

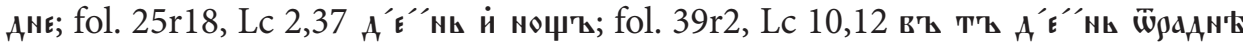

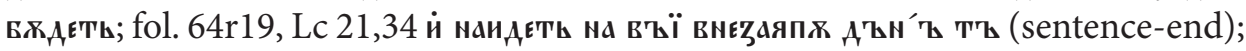

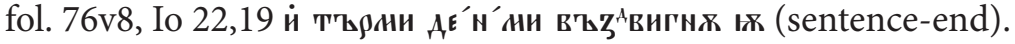

Only in two of these forms can the acute accent shapes be viewed as perhaps marking an omitted jer letter, as in nं் jer in $A^{\prime} \mathbf{N}^{\prime \prime}$ єшнеге (although there is no diacritic or titlo marking the omitted weak

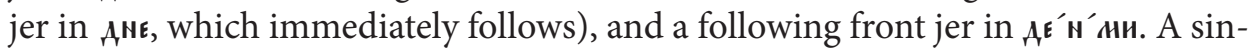
gle acute accent shape also appears over the form $A^{\top} \mathbf{b} \mathbf{H}^{\prime} \mathbf{Z}$, which, unusually for this manuscript, has $\mathbf{b}$ rather than $\mathbf{\varepsilon}$ for the strong jer in this word form. The fact that in four of the six forms the front jer is in strong position and written as $\mathbf{\varepsilon}$ indicates that the purpose of the diacritic in this root is not to mark a vocalic element

\footnotetext{
${ }^{45}$ Although the sentence containing $\Gamma^{\prime} \boldsymbol{\Lambda}^{\prime \prime}$ a mid-sentence, far enough away from the red incipit letter that it is unlikely to have been intended as

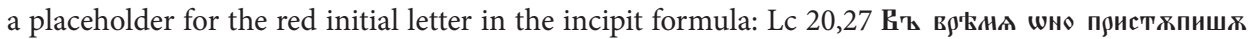

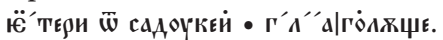

${ }^{46}$ Since I have not been able to identify any purpose for the dot over the preposition $\dot{\mathbf{B}} \mathbf{\mathbf { b }}$, I am tentatively considering it to have been a resting point for Dobrejšos pen.
} 
preceding the $/ \mathrm{n} /$ in the root. It remains unclear, however, what the point of the diacritic is in this form. Perhaps the original purpose was to disambiguate nominative/accusative singular $d b n b$ from the pronominal form $n b$ (not the conjunction $n \mathfrak{r}$, however, since that form is spelled through the manuscript as $\mathbf{\mu}$ ).

Triple acute accent shapes, and in one case a titlo, occur on three occasions over the preposition $n a$ in the phrase na nebo, and once over both elements

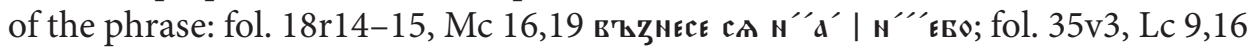

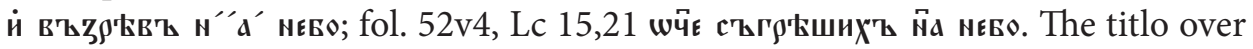
on $\mathbf{H} \mathbf{a}$ on fol. $52 \mathrm{v} 4$ may be a perseveration from $\boldsymbol{w} \bar{\varepsilon} \varepsilon$ in place of an intended triple acute accent. The diacritics over $n a$ in this phrase appear to have a disambiguating function, although it is unclear what that might be: perhaps to help the readers parse the phrase as two separate words, or to indicate stress on na within the phrase?

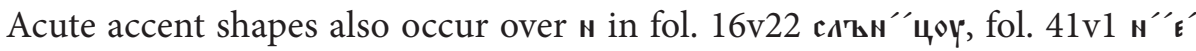
твори ии троуда' meant to highlight the beginning of the Lord's Prayer (which is also the beginning of the lection, as indicated by the red initial $\mathbf{0}$ ), so that it can be found easily by the reader. The other two occurrences are more difficult to explain. The double acute accent shapes in $\mathfrak{c} \mathbf{A}^{\prime} \mathbf{b} \mathbf{N}^{\prime \prime}$ 'ц이 may also be marking a (in this case historical) vocalic element between the consonants $/ \mathrm{n} /$ and $/ \mathrm{c} /$, like the dot over the cluster

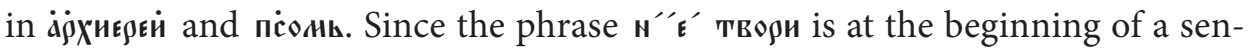
tence, perhaps the triple acute shapes are intended to show that, or to indicate sentence stress on $n e$ ?

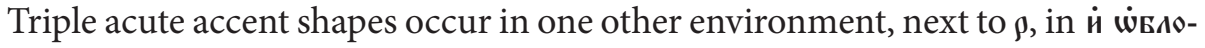

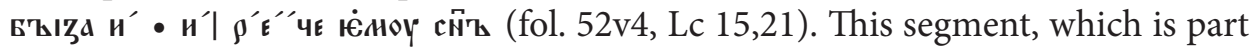

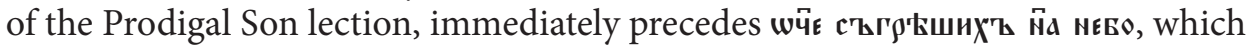
was discussed above in the context of the triple acute accent shapes that sporadically appear over na nebo. Although, according to the rubrication, the lection does

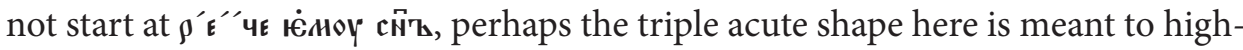
light the introduction to the son's famous speech, since one of the two most common incipit formulae begins with $r e c e^{47}$. If that is the case, then, to revisit the titlo over na, perhaps Dobrejšo felt obliged to use a different diacritic to mark na nebo later in the same line, and in the same sentence.

Thus the double and triple acute accent shapes in the phrases examined in this section appear to have multiple functions. What precisely these intended functions are is a matter of conjecture, but, as shown above in the case of $\mathbf{c}^{\prime} \mathbf{b} \mathbf{H}^{\prime \prime} \mathrm{L}_{\mathrm{O}} \mathrm{y}$, one of them appears to be the paerok-like marking of a vocalic element (in this case the etymological jer in the word) between the two consonants in the cluster. It remains unclear, however, why the manuscript marks a dropped weak jer letter, or a phonological vocalic element, only in these few instances.

\footnotetext{
${ }^{47}$ I.e., reče imz gospods (the other most common incipit formula being vo ono vrěmę).
} 


\section{Diacritics over forms of sobota}

The remaining environment for sporadic diacritics is over or near the jus major in sobot-. The whole gamut of diacritics is found here: dots, single acute accent shapes, triple acute accent shapes, and titla over unabbreviated word forms: fol. 4r5

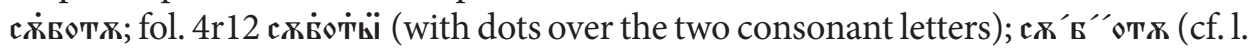

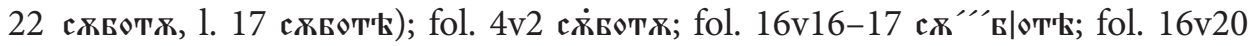

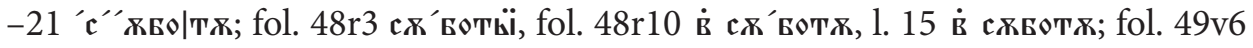

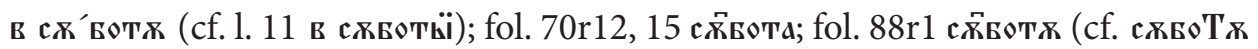
in the rubric on 1. 17). Since the diacritics are mostly above or next to the first $\pi$, it seems that this is where they were intended to go. In two of these instances, both on fol. 48r, a paerok-like dot appears over the preceding preposition $\dot{\mathrm{B}}$, appearing to

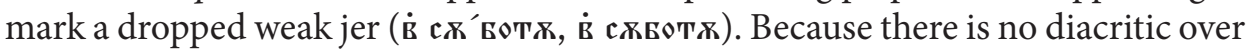
скБотк in the second occurrence, however, it seems likely that in both instances the dot was intended to be placed over сквотк rather than over $\dot{\mathbf{k}}$.

It is unlikely that the diacritic is intended to disambiguate the full word sobota from the abbreviated form that appears in the rubrics, because the latter is distinguished by a superscript letter $(\underset{\mathfrak{c} K}{\mathbb{E}})$. Perhaps it is meant to mark the word sobota as a nomen sacrum. If sobota were to be abbreviated in the text, as nomina sacra generally are, the usual abbreviation ${ }^{\mathfrak{k}} \boldsymbol{\delta}$ could indeed cause confusion, since it appears only in rubric instructions. A way to avoid confusion would be to add a titlo to the unabbreviated form of the word, as Dobrejšo does in the last three occur-

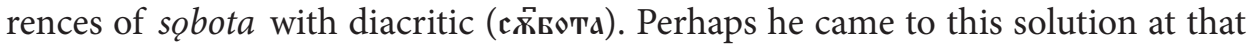
point in the text after finding unsatisfactory the multi-purpose dot and triple acute accent shapes that he had been using earlier for that purpose. A closer study of the distribution of textual environments for forms of sqbota with and without a diacritic may yield a clearer answer to this puzzle.

\section{Conclusion}

The most certain conclusion that can be drawn from the analysis above is that the sporadic dots, acute accent shapes, and superfluous titla in the Dobrejšo Gospel have more than one purpose apiece. Although their purposes in certain environments is presently unclear, and while it is often difficult to determine whether a given single dot or acute accent is a deliberate marking or a slip of the pen or resting point, nevertheless the following generalizations can be made on the basis of the diacritic patterns in the manuscript:

a. The dot and single acute accent shape are essentially two paleographic variants of a single diacritic. This is unsurprising, considering that in many medieval Slavic manuscripts that do not mark accentuation, hurriedly or carelessly executed superscript dots often look like acute accents. 
b. The double or triple acute accent shape is a different orthographic symbol from the dot or single acute accent shape, although their functions overlap.

c. The single dot or acute accent shape is used for the following purposes:

(i) to mark a vocalic element between two consonants that would otherwise be perceived as an unnatural cluster, in both canonical OCS trot spellings and certain OCS non-trot spellings with two consecutive consonant letters, one of which usu-

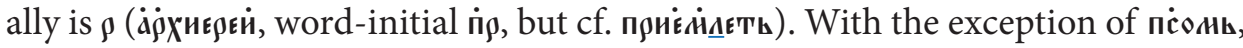
the consonant clusters that the two consecutive letters represent are not historically the result of a dropped weak jer, and in fact /pr/ is a fairly high-frequency Slavic cluster, as it occurs in several verb prefixes. On the other hand, since other spellings in the manuscript indicate that Dobrejšo's dialect did not preserve epenthetic $/ \mathrm{l} /$, the word-internal cluster $/ \mathrm{ml} /$ likely was uncommon for him;

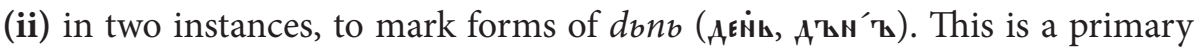
function of the double or triple acute accent shape (see (d)(iii) below);

(iii) in seven instances, to mark forms of the unabbreviated word sobota in the

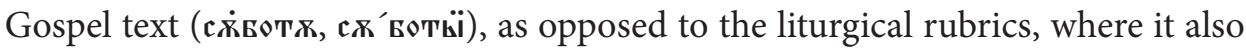
occasionally occurs in unabbreviated form. The fact that this word appears twice

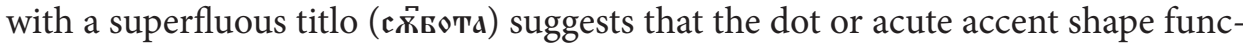
tions similarly to a titlo here in marking the word as a nomen sacrum. This word is also marked, less frequently, by double or triple acute accent shapes.

d. The double or triple acute accent shape is used sporadically for the following purposes, some of which overlap with the functions of the single dot or acute accent shape:

(i) in four instances, to indicate the insertion of a vocalic element into a perceived

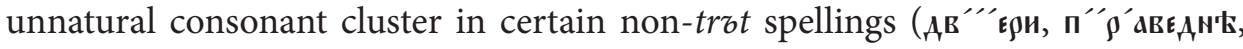
в'в弓"

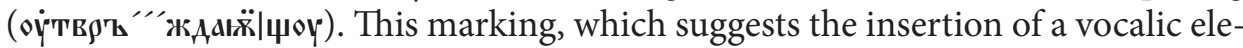
ment, is usually made with a single dot or acute accent shape (see (c)(i) above) $)^{48}$;

(ii) to mark words with the root glas- (e.g., $\left.\Gamma^{\prime} \mathbf{A}^{\prime \prime} \mathbf{A c s}_{\mathbf{c}}\right)$, probably in order to help the reader differentiate them from the abbreviation for the very high-frequency third person singular aorist form glagola ( $\overline{\Gamma \bar{a}}$ );

(iii) in four instances, to mark forms of the word $d b n \mathbf{b}\left(A^{\prime} \mathrm{E}^{\prime \prime} \mathrm{ML}\right)$ and, also on four occasions, the phrase na nebo ( $\mathbf{N}^{\prime \prime} \mathbf{A}^{\prime}$ NEБO). While the purposes of these markings is unclear (though once again, the marked words contain a sonorant), perhaps it is to highlight the word or phrase on the textual level, or, in the case of $\mathbf{N}^{\prime \prime} \mathbf{A}^{\prime} \mathbf{\text { NESO}}$, to indicate phrasal stress on the preposition. Forms of $d b n b$ are also marked with a single dot/acute accent shape (see (c)(ii) above);

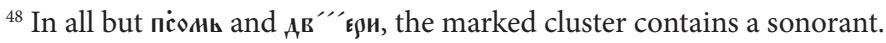


(iv) in three instances, to mark unabbreviated forms of the word sqbota in the Gospel text, probably in order to indicate that the word is a nomen sacrum

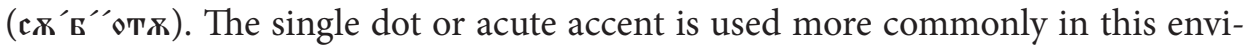
ronment (see (c)(iii) above);

(v) in two instances, apparently to highlight the beginning of a often-quoted

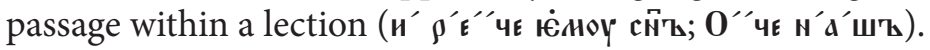

The overlap in functions between the single dot/acute accent shape, on one hand, and the double or triple acute accent shape, on the other, suggests that for Dobrejšo, these two diacritic types were more or less interchangeable, except in instances where he sought to highlight a word in the text. In those case, he used the multiple acute accent shapes, undoubtedly because they were more noticeable.

The above-described diacritics occur rarely, and only twice in an appropriate

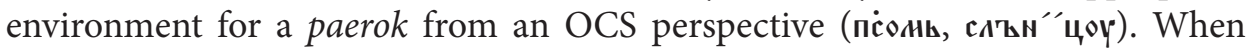
a diacritic occurs over $\rho$ left- or right-adjacently to another consonant letter (and

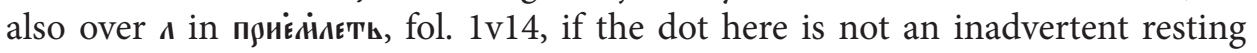
point), it appears to be marking a consonant cluster that Dobrejšo perceives as unnatural either on the phonological level, in the absence of an intervening vocalic element, or on the orthographic level, in the absence of a jer letter.

There remains the vexed question of the strict complementary distribution in the sporadic spellings of OCS trot vs. tlat forms: that is, why canonical OCS trot spellings in the manuscript sporadically include a dot or acute accent shape, suggesting the insertion of a vocalic element left-adjacent to the $/ \mathrm{r} /$, whereas OCS $t$ lot forms sporadically are written as tzlt but never as tlot with a diacritic. The orthographic distinction between OCS trøt and tlzt forms, when it occurs, probably reflects asymmetry in the reflexes of ${ }^{\star} T r r T /{ }^{*} T r z T$ and ${ }^{*} T z l T /{ }^{*} T l z T$ in Dobrejšo's vernacular dialect. A likely explanation is that, like certain modern western Bulgarian dialects, Dobrejšo's Middle Bulgarian dialect tended to have trort as the reflex of ${ }^{*} \operatorname{Tr} r T /{ }^{*} \operatorname{Tr} \sigma T$ (at least when not followed by another consonant), but $t l z t$ as the reflex of ${ }^{\star} T z l T /{ }^{*} T l z T$, with the exception of certain specific lexemes, some of which show up sporadically in the manuscript in tzlt spellings.

In conclusion, the most important issue regarding the diacritics in the Dobrejšo Gospel is not the use of a dot or acute accent shape over the letter $\rho$ to mark a preceding vocalic element, but rather the distribution of the diacritics. Rampant and maddening inconsistencies on both the orthographic and the dialectological levels present serious obstructions at this point to a definitive determination of the various functions of those dots and acute accent shapes in the manuscript that occur in environments other than sequences of two consonant letters. These inconsistencies include the sporadic and inconsistent placement of the diacritics; frequent ambiguities between dots and acute accent shapes (and between deliberate dots and inadvertent inkstains); a general tendency of scribes sometimes to miss the 
target letter when inserting diacritics; overlap in the environments where the scribe has used single vs. multiple diacritics; and asymmetry in numerous Bulgarian dialects between the reflexes of $\operatorname{Tr} r T /{ }^{*} \operatorname{Tr} r T$ and ${ }^{\star} T z l T /{ }^{\star} T l z T$, as well as variations within the reflexes of each of those two historical forms. The combination of these obstacles may make it impossible ever to know for certain what was going on in Dobrejšo's mind when he sporadically employed these diacritics, but further investigation may yield more certainty, particularly once an index verborum to the manuscript is completed. Meanwhile, there may be some reassurance in recalling that consistency is the hobgoblin of little minds.

\section{Bibliography}

\section{Sources}

Banica Gospel, НБКМ No. 847, Cyril and Methodius National Library, Sofia; typeset edition: Е. ДоГРАмАДЖИЕвА, Б. РАЙкОв, Банишко евангеле. Среднобългарски паметник от ХІІІ век, София 1981.

Curzon Gospel, Add MS 39,628, British Library; typeset edition: C.M. VAKareliysKa, The Curzon Gospel, vol. I, An Annotated Edition, Oxford 2008.

Dobrejšo Gospel, НБКМ No. 17 (307), Cyril and Methodius National Library, Sofia; typeset edition: Б. Цонев, Добрейтово четвероеванелие. Среднобългарски паметник от ХІІІ век (Софийска Нар. Библиотека №. 307 и Белградска Нар. Библиотека o. 214), БСт 1, 1906.

\section{Secondary literature}

Duma J., Wokalizacja jerów słabych $w$ rdzennej sylabie nagłosowej w południowo-wschodniej słowiańszczyźnie, Wrocław 1979.

Lehiste I., K. Popov, Akustische Analyse bulgarischer Silbenkerne, Phon 21, 1970, p. 40-48.

Lunt H.G., Old Church Slavonic Grammar, ${ }^{7}$ Berlin-New York 2001.

Lunt H.G., Old Church Slavonic Syllabic Liquids?, WS 7, 1962, p. 350-358.

Metzger B.M., Manuscripts of the Greek Bible: Introduction to Paleography, Oxford 1981.

Miletič LJ., Südslavische Dialektstudien, vol. II, Das Ostbulgarische, Wien 1903.

Scatton E., Syllabic-[r] and vowel/[r] Sequences in Some Southwest Bulgarian Dialects: I, LBa 36.1, 1993, p. 59-64.

Scatton E., Syllabic [r] and Schwa-[r] Sequences in Bulgarian Dialects: I. The Northwest, [in:] Alexander Lipson: In Memoriam, ed. C.E. Gribble, R.A. Rothstein, E.C. Haber, H.M. Olmsted, R. Szulkin, C.E. Townsend, Columbus 1994, p. 232-249.

Trubetzkoy N.S., Grundzüge der Phonologie, TCLP 8, 1938.

Vakareliyska C.M., Western Bulgarian or Macedonian? The Dobrejšo Gospel (XIII c.), Slo 50, 2010, p. 13-26, http://www.moderna.uu.se/slovo/Issue_Pages/2010issue50.html [14 XII 2014].

Vakareliyska C.M., The Dobrejšo Gospel: An Annotated Edition and Comparative Analysis (forthcoming). 
Бояджиев Т., Български говори в западна (беломорска) и източна (одринска) Тракия, София 1991.

Български диалектичен атлас. Обобщаващ, том, vol. I-III, Фонетика, Акцентология, Лексика, ed. И. Кочев et al., София 2001.

ДЕСПодова В., Л. СлАвевА, Македонски средновековни ракописи, Прилеп 1988.

Колесов В.В., Надстрочные знаки «силь» в русской орфографической традиции, [in:] ВосточноставянсКИе ЯзыКИ. ИсточнИКИ для ИХ ИзУченИЯ, еd. Л.П. ЖУКОВСКАЯ, Н.И. ТАРАБАСОВА, Москва 1973, р. 228-257.

Конески Б., История на македонскиот јазик, Скопје 1965.

Марков В.М., К истории редуцированных гласных в русском языке, ${ }^{2}$ Казань 2007.

Тотоманова A.-М., За природата и съдбата на гласната ^ в българския език, [in:] еADEм, Из българската историческа фонетика, София 2001, p. 45-67.

\begin{abstract}
This paper examines the distribution of three types of sporadic and infrequent diacritics in the Dobrejšo Gospel and their functions: a dot or acute-accent shape over a liquid consonant letter in OCS trat/trbt formations, and, more rarely, over other consonant letters in clusters; a single or multiple acute-accent shape over the letter $\boldsymbol{\Lambda}$ or $\mathbf{~} \mathbf{~ i n ~ c e r t a i n ~ w o r d s ; ~ a n d ~ a ~ t i t l o ~ o v e r ~ u n a b b r e v i a t e d ~}$ words containing OCS trat/trbt formations.
\end{abstract}

Keywords: Old Church Slavonic, Bulgarian Church Slavonic, Slavic linguistics, medieval Slavic manuscripts, liquid consonants, vocalic liquids, historical Slavic phonology, Gospels.

Cynthia M. Vakareliyska

University of Oregon

Department of Linguistics

Eugene, OR 97403, USA

vakarel@uoregon.edu 